\title{
A Research on International Commercial Arbitration with reference to the Brexit
}

\author{
S. Sadhana, S. Bhuvaneswari
}

\begin{abstract}
International commercial arbitration is an alternative method of dispute resolution. It is regarding disputes arising out of commercial transactions conducted across national boundaries and it allows the parties to bypass litigation in their national courts. The aim of the researcher is to understand how the position of London as the favoured seat of Arbitration will change after Brexit. Secondly, the paper also focuses on the use of international arbitration as a tool to solve investor-state disputes.

The present paper was analysed through the non-doctrinal research methodology and empirical and descriptive method of research was used. The present analysis was made through random sampling method where the survey was taken from common public, professionals, etc through a structured questionnaire. The sample size in the present analysis is 1669 samples. The research tools used in the present paper are cross tabulation, chi-square and frequency.

It can be concluded that the position of London as the popular seat of arbitration will not be affected as the English Law is generally considered as the immediate choice of law for around most of the commercial contracts. Secondly, as far as investorstate dispute resolution is considered, arbitration can become a popular choice in future after the amendments were made in 2017 to make it more transparent and cost efficient.
\end{abstract}

Keywords: Arbitration, Brexit, Confidentiality, Investor-State Disputes, Jurisdiction, Settlement

\section{INTRODUCTION}

International commercial arbitration is an alternative method of dispute resolution. It is regarding disputes arising out of commercial transactions conducted across national boundaries and it allows the parties to bypass litigation in their national courts.

It has been defined in Section 2(1)(f) of the Arbitration and Conciliation Act, 1996. It simply means an arbitration relating to any dispute arising out of legal relationships and it should be considered as commercial.

The scope of Section 2(1)(f) was determined in TDM Infrastructure Pvt. Ltd. v. UE Development India Pvt. Ltd where the Supreme Court held that despite the company having a foreign control, "a company incorporated in India can only have Indian nationality for the purpose of the Act."

International Commercial Arbitration can simply be understood as a particular means of settling disputes, i.e. by "arbitration" that is "commercial" in nature and has some international element to it.(Unctad-Ictsd and UNCTAD-

Revised Manuscript Received on 14, October 2019.

S. Sadhana, V ${ }^{\text {th }}$ year B. A. LL. B, Saveetha School of Law,Saveetha University, Chennai, Tamilnadu, India. (E-mail:

S. Bhuvaneswari, Assistant Professor of Law, Saveetha School of Law, Saveetha Institute of Medical and Technical Sciences (SIMATS), Saveetha University, Chennai, Tamilnadu, India. (E-mail: bhuvaneshwaris.ssl@saveetha.com) Institute of Medical and Technical Sciences (SIMATS),Saveetha sadhanamadhavan1997@gmail.com)

ICTSD) Article 1 (3) of the Model Law of the United Nation Commission on International Trade Law (UNCITRAL) has mentioned that arbitration will be considered to be international if it falls under any of the categories mentioned.

Now, the word commercial includes the trade and commerce and includes any activity which results in profits. This has now become a part of the international trade.

As far as international arbitration is considered, presently, London is considered as the most favourable seat of arbitration. After the London exits the European Union, a direct impact will be seen in the social and political scenario of London. In one area where arbitration has not managed to become popular is investor-state dispute settlement. Arbitration is not preferred in the case of dispute settlement of investor-state due to the fact that it is not practical to be considered a favourable mechanism.

Objectives:

- To discuss the role of international commercial arbitration in the present era.

- To understand how the position of London as the favoured seat of Arbitration will change after its exit from the European Union.

- To analyse the use of Arbitration to resolve investor-state disputes.

\section{LITERATURE REVIEW}

(Luttrell) considers arbitration to be a flexible process in the determination of the rights of the parties and that the arbitral awards are portable but the significant risk is the element of bias that may exist against the foreign party which has been analysed in this book. (Lew et al.) have given an overview on arbitration and in particular discussed the major advantages of arbitration like expert arbitrator, confidentiality, speedy expedition and cost. However, in some cases international arbitration does take some time. But still it is faster than the courts. (Friedland) while discussing the advantages of international arbitration, feels that international arbitration at its core remains as it was despite the growing importance attached to it. It is a private way of settlement of disputes chosen by the parties themselves. (Noussia) has tried to understand how confidentiality might entice the parties go for arbitration and the surrounding sociological impacts. The author then tried to understand how confidentiality is understood by the judiciary. 
(van den Berg) has focussed on international commercial arbitration and its relevance with regard to the establishment of UNCITRAL. The UNCITRAL was established in 1966 by the General Assembly to harmonize international trade disputes and facilitate a harmonized dispute settlement mechanism. The Commission has adopted the UNCITRAL Arbitration Rules in 1976 to give a comprehensive set of rules upon which the parties may conduct the arbitral proceedings. These rules have largely governed the international commercial arbitration and is a model law in this regard.

(Moses) has put forth that arbitration indicates the voluntary relinquishment of judicial service to resolve a dispute. He, further, states that arbitration has become the most popular method of dispute resolution. Arbitration allows the parties to choose their arbitrators giving them the freedom to govern the procedure. He goes on to state that it is better for the parties to decide on the terms of arbitration at the beginning the relationship while they are still on good terms.

(Greenberg et al.) have posited that arbitration is governed as 'ex aequo et bono and amiable compositeur'. This means the decision is based on the principles of fairness and justice and not by the law. Discussion has been done on the validity of the main contract and arbitration agreement. Here, it must be understood that the parties are concluding two agreements and not just one. Validity of the arbitration agreement must not depend on the validity of the other parts of the agreement as the arbitral tribunal can declare the other parts of the contract invalid but still retain its jurisdiction to deliver the decision.

(Marchisio) has tried to highlight that arbitrators approach the issues of validity of the arbitration agreement as a jurisdictional matter. They determine the validity on three grounds:- the application of the law of the contract chosen by the parties; the règles matérielles de l'arbitrage international; and the conflict of law rules. Generally, the courts do not interfere in the arbitral order and intervene only in the post-award phase, thereby, maintaining the autonomy of the arbitral award.

("Contracts: Validity of Arbitration Agreement") has further analysed the validity of arbitration agreement and how it directly questions the jurisdiction of the arbitrator and the validity of the arbitral award. Deeper understanding of the arbitration law and public policy has been done.

(Born) has compiled a list of issues surrounding international commercial arbitration and has dealt in detail with each issue while citing national decisions and the law supporting the same. (Cuniberti) has tackled the role of consent as far as international commercial arbitration. The author has stressed that even after the arbitration agreement, the consent of the parties must be sought after the dispute has arisen as in general, arbitration is not favourable to a party with a weaker economic stability as they might not be able to afford two or three arbitrators and might end up not pursuing the case. The cost factor which was earlier discussed as an advantage has clearly been pointed as a major disadvantage here.

(Gaitskell) has analysed the procedures in Hong Kong, India, England and Wales, Brazil, the United States, Italy and Slovakia are reviewed in detail. Finally, he deals with
Arbitration as a mode of dispute resolution and the enforcement of arbitral awards.

(The Economist) while analysing the role of arbitration has stressed upon how arbitration is hardly used in resolving investor-state disputes due its various flaws and that the system needs to be made more user-friendly. The system was brought in with good intentions but its implementation mechanism has not been particularly desirable.

(Varapnickas) in his paper has discussed in depth the impact of Brexit and how it shall affect London as the favorable seat for arbitration. The author feels that the Brexit will have a positive impact on London as the favourable seat for arbitration as the exit might help the UK to recover its right to decide on all issues related to arbitration, including anti-suit injunctions, interpretation of public policy. This was curbed when UK was the member state of the European Union. Further, (Al-Nuemat and Nawafleh) has substantiated this by stating that the UK will no longer be forced to follow the problematic aspects of European law which will further cement London's position as the favourable seat. He goes on to state that the English Law will continue to be significant as the history of English dispute tribunals show that they were designed with an international perspective which makes it popular among all countries. (Trevellick) has further substantiated that London will remain unaffected as it has the backing of law which facilitates a smoother process in the course of arbitral proceedings. The Arbitration Act of 1996 in the UK will largely remain unaffected by Brexit and it will continue to remain in force. In a survey undertaken in 2018 by the School of International Arbitration, Queen Mary University of London, in partnership with White \& Case, it was seen that majority of the respondents of the international survey have stated that Brexit will not have much of an impact on London as the favourable seat of Arbitration.

\section{METHODOLOGY}

The present paper was analysed through the non-doctrinal research methodology and empirical and descriptive method of research was used. The present analysis was made through random sampling method where the survey was taken from common public, professionals, etc through a structured questionnaire. The sample size in the present analysis is 1669 samples which has been indicated in the Table 1. The independent variable in this analysis is the age and the dependent variable is reliable on the opinion of the respondent regarding the impact of Brexit on London as the favoured seat of Arbitration. The research tools used in the present paper are cross tabulation, chi-square and frequency.

\section{ANALYSIS AND DISCUSSION}

\section{Hypotheses:}

$\mathrm{H}_{0}$ : There is no significant association between the age of the respondent and their opinion regarding the impact of Brexit on the position of London as the favoured seat of arbitration. 
$\mathrm{H}_{1}$ : There is a significant association between the age of the respondent and their opinion regarding the impact of Brexit on the position of London as the favoured seat of arbitration.

Table 1.0: Cross Tabulation of Age of respondents and the Opinion of the respondents regarding the impact of Brexit on London as the favoured seat of Arbitration

\begin{tabular}{|c|c|c|c|c|c|c|}
\hline Age & $\begin{array}{l}\text { Strongly } \\
\text { Disagre } \\
\text { e }\end{array}$ & $\begin{array}{l}\text { Dis } \\
\text { agr } \\
\text { ee }\end{array}$ & $\begin{array}{l}\mathrm{Neu} \\
\text { tral }\end{array}$ & $\begin{array}{l}\text { Agr } \\
\text { ee }\end{array}$ & $\begin{array}{l}\text { Strong } \\
\text { ly } \\
\text { Agree }\end{array}$ & $\begin{array}{l}\text { Tot } \\
\text { al }\end{array}$ \\
\hline $18-$ & 31 & 16 & 151 & 71 & 8 & 424 \\
\hline $\begin{array}{l}26- \\
35\end{array}$ & 19 & $\begin{array}{l}14 \\
9\end{array}$ & 116 & 318 & 40 & 642 \\
\hline $\begin{array}{l}36- \\
45\end{array}$ & 48 & $\begin{array}{l}22 \\
3\end{array}$ & 101 & 83 & 36 & 491 \\
\hline $\begin{array}{l}\mathrm{Ab} \\
\text { ove } \\
46\end{array}$ & 14 & 28 & 33 & 16 & 21 & 112 \\
\hline Total & 112 & $\begin{array}{l}56 \\
3\end{array}$ & 401 & 488 & 105 & $\begin{array}{l}166 \\
9\end{array}$ \\
\hline
\end{tabular}

From the Table 1.0, It can be seen that $40.4 \%$ of the respondents disagree that Brexit will have an impact on London as the favourable seat of Arbitration. 35.6\% of the respondents feel that Brexit will have an impact on the position of London as the favourable seat of arbitration. $24 \%$ of the respondents remain neutral in this regard. This can indicate their lack of awareness on the subject. It can be analysed from the results that respondents feel that the position of London as the popular seat of arbitration will not be affected as the English Law is generally considered as the immediate choice of law for around most of the commercial contracts. Also, generally, the English legal system is perceived as neutral and impartial and the legislative framework applicable to arbitration and the English courts continue to be in favour of arbitration. Fourthly, the UK will continue to be a party to the 1958 New York Convention on the Recognition and Enforcement of Foreign Arbitral Awards. All the above things remain unchanged. The Court in West Tankers case has held that an anti-suit injunction obtained in the English courts against a party who brought court proceedings in Italy in breach of an arbitration agreement was incompatible with European Union Law. This judgement was found to be largely favourable to the practitioners of the Civil Law system and had significant implications for arbitration in London as London practitioners consider anti-suit injunctions in favour of arbitration and as an essential to uphold arbitration agreements with a London seat Hence, it is indicated that the UK might become the immediate choice in future, mainly because it will no longer be bound by the complex laws of the European Union. Thus, analysis of the results clearly indicate that age of the respondent has an influence on their responses.
Table 1.1: Result of Chi-Square Tests - Age of respondents and the Opinion of the respondents regarding the impact of Brexit on London as the favoured seat of Arbitration

\begin{tabular}{|l|l|l|l|}
\hline & Value & df & $\begin{array}{l}\text { Asymp. Sig. (2- } \\
\text { sided) }\end{array}$ \\
\hline $\begin{array}{l}\text { Pearson Chi- } \\
\text { Square }\end{array}$ & $\begin{array}{l}298.1 \\
61^{\mathrm{a}} \\
\text { Likelihood } \\
288.7\end{array}$ & 12 & .000 \\
$\begin{array}{l}\text { Ratio } \\
\text { N of Valid } \\
\text { Cases }\end{array}$ & 04 & 12 & .000 \\
\hline
\end{tabular}

a. 0 cells $(0.0 \%)$ have expected count less than 5 .

The minimum expected count is 7.05 .

Based on the Pearson value from Table 1.1, it can be seen that the alternate hypothesis is considered which rejects the null hypothesis. This means that the age of the respondent and the dependent variable. Analysing, Table 1.0 deeply, it can be inferred that more than half of the respondents between the age group of 26-35 have agreed to the statement. In fact, the majority of the respondents belonging to the other age groups have largely disagreed with the statement. This shows that the

Table 2.0: Cross Tabulation of Age of respondents and the Opinion of the respondents regarding the increase in the use of international arbitration to resolve investor-State disputes in future

\begin{tabular}{|c|c|c|c|}
\hline Age & Yes & No & Total \\
\hline $18-$ & 269 & 155 & 424 \\
\hline $\begin{array}{l}26- \\
35\end{array}$ & 408 & 234 & 642 \\
\hline $\begin{array}{l}36- \\
45\end{array}$ & 256 & 235 & 491 \\
\hline $\begin{array}{l}\mathrm{Ab} \\
\text { ove } \\
46\end{array}$ & 61 & 51 & 112 \\
\hline Total & 994 & 675 & 1669 \\
\hline
\end{tabular}

It can be seen from the above table that $59.5 \%$ of the respondents feel that arbitration might be the most sought after tool to resolve investor-State disputes. Further, the results indicate that arbitration might become a popular choice of investor-state dispute settlement. This is not surprising as the system was recently amended in 2017. Earlier, it faced too many criticisms to be the first choice. In fact, UNCITRAL has entrusted the Working Group III with a broad mandate to work on the possible reform of the ISDS framework and are looking to make it more approachable. This was done with the intention to protect foreign investors from discrimination. But this idea has not been executed properly. Changes have been made to make it more transparent and cost efficient. 


\section{CONCLUSION AND RECOMMENDATIONS:}

It is to be seen how the negotiations between the UK and EU will go and only then, can it be concluded that Brexit might have positive impact to international arbitration in the UK. In so far, the UK is a popular place for arbitration. This is mainly because English Courts situated in London are attractive to the parties as they stand after being 'tried and tested'. Also, earlier, the UK was forced to not apply instruments such as anti-suit injunctions towards the other EU member states. This was because it was bound by the EU laws. Now, this might come to an end with Brexit. UK might become independent and restore its right to decide on all the issues without being confined by the EU laws. It is however difficult to predict the long term impact of Brexit on International Arbitration. This might have led to the indecisiveness of certain respondents.

As far as the settlement of investor-state disputes through arbitration is considered, it is opined that a permanent body and an appeal mechanism can be created to ensure that the system is not consistent. This is because arbitration depends on the principles of natural justice and how they are interpretation. This results in inconsistencies and discrepancies which might be partially resolved by the creation of a permanent body. But either is not the magical solution to the problem and it definitely needs some more reforms to become fully functional and approachable. This might have been the reason behind the disagreement of $40 \%$ of the respondents.

\section{REFERENCES:}

1. Al-Nuemat, Ahmed, and Abdullah Nawafleh. "Brexit, Arbitration and Private International Law." Journal of Politics and Law, vol. 10, no. 5, 2017, p. 116, doi:10.5539/jpl.v10n5p116.

2. Born, Gary. International Commercial Arbitration: Commentary and Materials. Transnational Pub Incorporated, 2001.

3. "Contracts: Validity of Arbitration Agreement." Michigan Law Review, vol. 23, no. 8, 1925, p. 911, doi:10.2307/1278877.

4. Friedland, P. D. "The Law and Practice of International Commercial Arbitration by Alan Redfern and Martin Hunter." Arbitration International, vol. 4, no. 1, 1988, pp. 76-79, doi:10.1093/arbitration/4.1.76.

5. "London Will Remain Seat of Arbitration, despite Brexit." The Peninsula Qatar, 3 Apr. 2019, https://thepeninsulaqatar.com/article/03/04/2019/London -will-remain-seat-of-arbitration,-despite-Brexit.

6. Noussia, Kyriaki. Confidentiality in International Commercial Arbitration. 2010, doi:10.1007/978-3-64210224-0.

7. The Economist. "The Arbitration Game." The Economist, The Economist, 2014 https://www.economist.com/finance-andeconomics/2014/10/11/the-arbitration-game.

8. Unctad-Ictsd, and UNCTAD-ICTSD. "Dispute Settlement." Resource Book on TRIPS and Development, pp. 651-704, doi:10.1017/cbo9780511511363.034. 